\title{
ULTRASOUND IN DIAGNOSIS AND MANAGEMENT OF ACUTE HAEMATOGENOUS OSTEOMYELITIS IN CHILDREN
}

\author{
C. B. HOWARD, M. EINHORN, R. DAGAN, M. NYSKA
}

From Ben-Gurion University of the Negev, Be'er-Sheva, Israel

We reviewed the ultrasound findings in 59 children suspected of having bone infection. Twenty-nine were eventually proved to have acute haematogenous osteomyelitis and 26 of these showed characteristic ultrasound findings. Such changes were rare in 30 patients with other clinically similar conditions. Ultrasound examination was also able to detect the presence of subperiosteal pus and thus indicate the need for surgical treatment.

J Bone Joint Surg [Br] 1993:75-B: 79-82.

Received 24 March 1992; Accepted 29 May 1992

The diagnosis of acute haematogenous osteomyelitis in childhood may be difficult. Early treatment improves the long-term prognosis and reduces the need for operation (Cole, Dalziel and Leitl 1982), the risk of permanent damage, and the likelihood of recurrence (Harris 1960; Ek 1971; Nade 1983). The early clinical signs may be minimal, non-specific and difficult to elicit in an uncooperative child.

Routine investigations may give little help. The ESR and white cell count may be normal or they may be elevated by an unrelated condition. Plain radiographs are usually of little value, although it has been claimed that there may be loss of soft-tissue planes early in the disease (Capitanio and Kirkpatrick 1970). Positive cultures from blood or bone may help, but even bone aspiration has a $20 \%$ to $40 \%$ false-negative rate (Dich, Nelson and Haltalin 1975; Waldvogel and Vasey 1980; Scott et al 1990; Gold 1991). Radionucleotide bone scans are not specific, and may be misleading (Fleisher et al

C. B. Howard, FRCS, Consultant Orthopaedic Surgeon

M. Nyska, MD. Consultant Orthopaedic Surgeon

Department of Orthopaedic Surgery, Soroka Medical Centre of Kupat

Holim, Ben-Gurion University of the Negev, Be'er-Sheva, Israel.

M. Einhorn, MD, Lecturer

R. Dagan, MD, Professor

Paediatric Infectious Diseases Unit, Soroka Medical Centre of Kupat

Holim. Ben-Gurion University of the Negev, Be'er-Sheva, Israel.

Correspondence should be sent to $\mathrm{Mr} \mathrm{C}$. B. Howard.

(1)1993 British Editorial Society of Bone and Joint Surgery $0301-620 \times / 93 / 1476 \$ 2.00$
1980; Scoles, Hilty and Sfakianakis 1980; Sullivan et al 1980). Like CT scans, they may not be available for an urgent admission.

The primary lesion of haematogenous osteomyelitis is within the bone, but the surrounding soft tissues are very soon involved. Ultrasound cannot penetrate dense bone, and may be considered an inappropriate investigation for osteomyelitis, but it can show early changes in the soft tissues. Abiri, Kirpekar and Ablow (1989) demonstrated subperiosteal abscesses in four cases of haematogenous osteomyelitis in immune-deficient adults, and we have described four children in whom it was possible to show a collection of pus between the periosteum and the outer cortex (Howard and Einhorn 1991).

We have now reviewed our experience of the use of ultrasound in 59 children suspected of having osteomyelitis. We assessed its ability to detect the soft-tissue changes, to distinguish between osteomyelitis and other conditions, and to predict which patients need operation.

\section{PATIENTS AND METHODS}

From March 1988 to November 1991, we performed ultrasound examinations on 59 children in whom there was a suspicion of osteomyelitis, using a Sonoline SL1 with a $5 \mathrm{MHz}$ or $7.5 \mathrm{MHz}$ linear transducer. Twentynine were eventually proved to have had osteomyelitis. There were 18 boys and 11 girls; their average age was 6.3 years (0 to 15), and in two patients three sites were involved, giving a total of 33 sites examined. We excluded two patients ( 3 sites) in whom the iliac bone was involved.

A positive diagnosis of osteomyelitis was made if there were definite findings at operation, or at least two of the following three conditions were fulfilled: positive bone culture, positive bone scan, and characteristic changes on plain radiographs.

The other 30 children had a variety of other diagnoses (group 2). These and the ultrasound findings are given in Table I.

\section{RESULTS}

In the children shown to have osteomyelitis there were 
Table I. Diagnosis and ultrasound findings in 30 children with symptoms suggestive of osteomyelitis

\begin{tabular}{|c|c|c|}
\hline Diagnosis & Number & Ultrasound \\
\hline C'ellulitis & 9 & $\begin{array}{l}\text { Swelling and decreased echogenicity } \\
\text { with small collections of fluid within } \\
\text { the superficial fascia }\end{array}$ \\
\hline Septic arthritis & 6 & Fluid within the joint \\
\hline Soft-tissue abscess & 5 & $\begin{array}{l}\text { Discrete well-defined hypo-echogenic } \\
\text { area within the soft tissues }\end{array}$ \\
\hline Myositis & 3 & $\begin{array}{l}\text { Loss of normal architecture } \\
\text { Localised decreased echogenicity of } \\
\text { the muscle }\end{array}$ \\
\hline Prepatellar bursitis & 2 & $\begin{array}{l}\text { Decreased echogenicity over the } \\
\text { patella }\end{array}$ \\
\hline Muscle trauma & 2 & $\begin{array}{l}\text { Increased thickness of the muscle. } \\
\text { retaining normal architecture. No } \\
\text { periosteal changes }\end{array}$ \\
\hline Myositis periostitis & 1 & Similar to osteomyelitis \\
\hline Gaucher's disease & 1 & Similar to osteomyelitis \\
\hline Fosinophilic granuloma & 1 & Similar to osteomyelitis \\
\hline
\end{tabular}

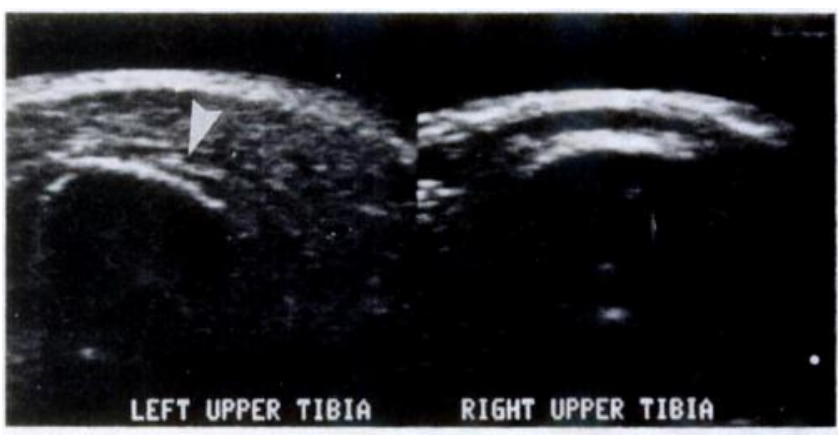

Fig. 1

Transverse ultrasound scans of both upper tibiae. On the left side the periosteum is thickened (arrow) and surrounded by hypo-echogenic (black) regions. The overlying soft tissues are also swollen.

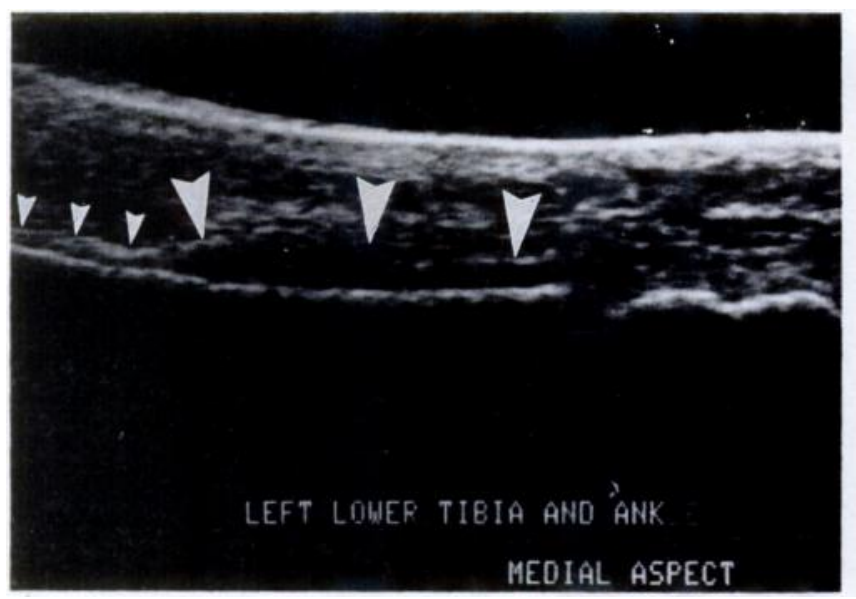

Fig. 2

A longitudinal view of the distal tibia. The periosteum over the distal bone is elevated (large arrows), and separated from the cortex by an echoless zone. More proximally the periosteum remains attached to the bone (small arrows). three characteristic ultrasound findings:

1) Thickening of the periosteum, with hypo-echogenic zones both superficial and deep to it, giving the appearance of a 'sandwich' (Fig. 1).

2) Elevation of the periosteum by more than $2 \mathrm{~mm}$; in severe cases there were both echoless and moderately echogenic zones between the periosteum and the cortex (Fig. 2).

3) Swelling of overlying muscle or subcutaneous tissue, maximal nearest to the bone, with altered echogenicity of the tissue depending on the angle of scan (Figs 1, 3). This was present in all but one case.

The type I changes were seen at 12 sites in 11 patients (Table II). All but two had presented within three days of the onset of symptoms. Five sites in four children eventually required operations, and at three sites in two children intramedullary pus was found. One child required drainage of an infected haematoma which had resulted from needle aspiration of the bone the previous day, and no pus was found in the fourth child at operation eight hours after admission. It is uncertain

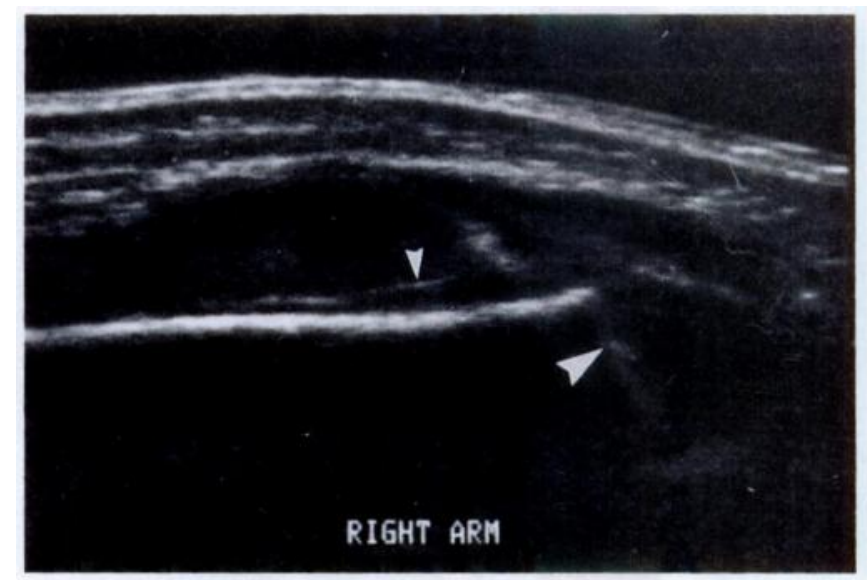

Fig. 3a

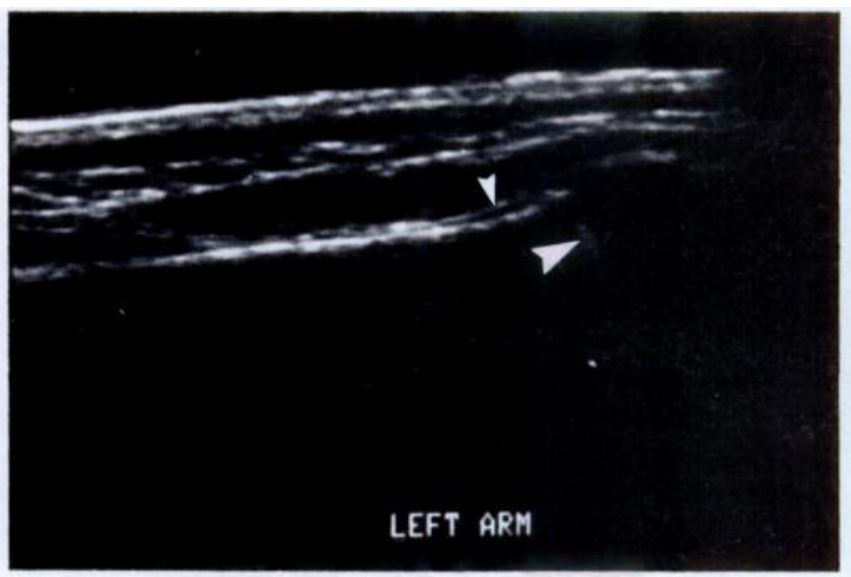

Fig. 3b

Longitudinal views of both humeri. The head of the humerus is on the right in both views; the growth plates are marked by large arrows and the periosteum by small arrows. In the right arm the periosteum is elevated and the overlying deltoid muscle is swollen. 
Table II. Details of 27 patients ( 30 sites) with positive ultrasound findings and a diagnosis of haematogenous osteomyelitis

\begin{tabular}{|c|c|c|c|c|}
\hline Case & $\begin{array}{l}\text { Age } \\
(\mathbf{y r})\end{array}$ & $\begin{array}{l}\text { History } \\
\text { (days) }\end{array}$ & Site & Operative finding \\
\hline \multicolumn{5}{|c|}{ Periosteal sandwich } \\
\hline 1 & 4 & 3 & Distal femur & \multirow{7}{*}{ No operation } \\
\hline 2 & $7 \mathrm{mth}$ & i & Proximal tibia & \\
\hline 3 & $8 \mathrm{mth}$ & 8 & Distal humerus & \\
\hline 4 & 4 & 3 & Proximal tibia & \\
\hline 5 & 1.3 & 1 & Proximal tibia & \\
\hline 6 & 7 & 1 & Distal tibia & \\
\hline 7 & 1.7 & 7 & Proximal tibia & \\
\hline 8 & 8 & 3 & $\begin{array}{l}\text { Proximal tibia } \\
\text { Distal femur }\end{array}$ & \multirow{4}{*}{$\begin{array}{l}\text { Intramedullary pus } \\
\text { Intramedullary pus } \\
\text { Intramedullary pus } \\
\text { Infected } \\
\text { haematoma }\end{array}$} \\
\hline 9 & 5 & $?$ & Proximal tibia & \\
\hline 10 & 15 & 2 & Distal tihia & \\
\hline 11 & 15 & 3 & Proximal tibia & \\
\hline \multicolumn{5}{|c|}{ Periosteal elevation } \\
\hline 1 & 15 & 7 & Clavicle & \multirow{16}{*}{ Subperiosteal pus } \\
\hline 2 & 1.5 & ? & Proximal humerus & \\
\hline 3 & 7 & 3 & Fibula & \\
\hline 4 & 12 & 3 & Distal tibia & \\
\hline 5 & 9 & 3 & Rib & \\
\hline 6 & 2 & 1 to 3 & Distal femur & \\
\hline 7 & 7 & & Distal radius & \\
\hline \multirow[t]{3}{*}{8} & 10 days & 2 to 3 & Proximal humerus & \\
\hline & 10 days & 2 to 3 & Distal ulna & \\
\hline & 10 days & 2 to 3 & Proximal femur & \\
\hline 9 & 10 & 7 & Distal radius & \\
\hline 10 & 6 & 3 & Distal tibia & \\
\hline 11 & 9 & 2 & Distal tibia & \\
\hline 12 & 4 & 4 & Distal femur & \\
\hline 13 & 6 & 5 & Proximal humerus & \\
\hline 14 & 6 & 8 & Proximal humerus & \\
\hline 15 & 9 & 7 & Distal femur & Granulation tissue \\
\hline 16 & 15 & 3 & Pubis & Granulation tissue \\
\hline
\end{tabular}

Table III. Correlation of operative and ultrasound findings in osteomyelitis (all bones other than the ilium)

\begin{tabular}{|c|c|c|}
\hline \multirow[b]{2}{*}{ Operative findings } & \multicolumn{2}{|c|}{ Ultrasound findings } \\
\hline & $\begin{array}{l}\text { Periosteal } \\
\text { sandwich }\end{array}$ & $\begin{array}{l}\text { Periosteal } \\
\text { elevation }\end{array}$ \\
\hline Subperiosteal abscess & 0 & 16 \\
\hline $\begin{array}{l}\text { No subperiosteal abscess } \\
\text { but pus in medulla }\end{array}$ & 3 & 0 \\
\hline No pus found & 1 & 0 \\
\hline Granulation tissue & 0 & 2 \\
\hline Infected haematoma & 1 & 0 \\
\hline $\begin{array}{l}\text { No operation (conservative } \\
\text { management) }\end{array}$ & 7 & 0 \\
\hline Total & 12 & 18 \\
\hline
\end{tabular}

whether she would have responded to conservative management. No subperiosteal pus was found at operation in any of these cases (Table III).

A bulging, elevated periosteum was seen at 18 sites in 16 patients. All these children had an operation: subperiosteal pus was present at 16 of the sites, and subperiosteal granulation tissue was found at two (Table II).

Some periosteal changes were found in all patients proved to have osteomyelitis, with the exception of three

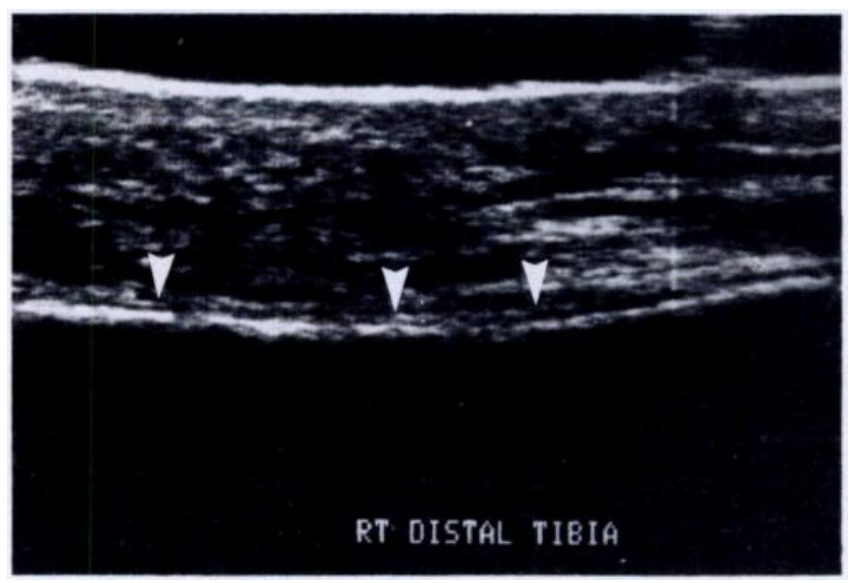

Fig. 4

A longitudinal ultrasound scan in a case of cellulitis overlying the tibia. The subcutaneous fat appears swollen and contains black areas, which represent either minute abscesses or collections of oedema fluid. The periosteum (arrows) remains unaffected.

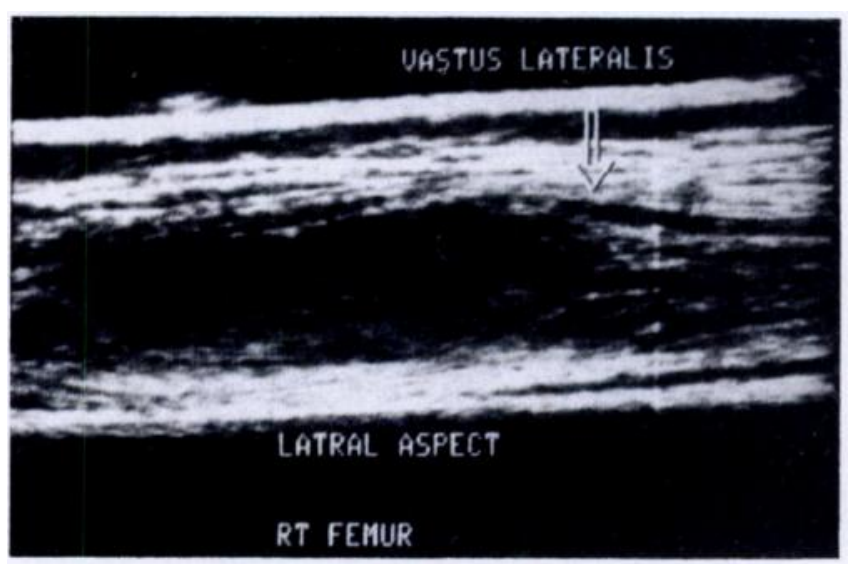

Fig. 5

A longitudinal ultrasound scan in a case of myositis of the vastus lateralis muscle. The muscle to the left of the arrow is swollen.

with osteomyelitis of the ilium. In one of these an abscess overlying the bone was seen on ultrasound, and this was confirmed at surgery. In the other two, ultrasound showed only soft-tissue swelling which responded to parenteral antibiotics and did not require surgery.

In all but three of the 30 patients with other conditions, the ultrasound appearances were different from those of osteomyelitis (Table II). In cases of softtissue infection the periosteum was not involved; swelling and changes in tissue architecture were concentrated in the affected tissue. Two such cases are shown in Figures 4 and 5 .

The three false-positive cases showed the ultrasound characteristics of osteomyelitis. The first was eventually diagnosed as a bone crisis in a patient with Gaucher's disease. Biopsy showed no inflammatory condition, but Gaucher cells were seen. The second patient had a lytic lesion in the humerus, with periosteal elevation, which 
proved to be an eosinophilic granuloma. The third was a case of infected traumatic myositis. Ultrasound confirmed this diagnosis, but showed a periosteal sandwich in one area. Biopsy showed that the periosteum was inflamed, but that the underlying bone was not affected.

\section{DISCUSSION}

Osteomyelitis produces changes in the contiguous soft tissues which can be seen on ultrasound. They occur very early, and could be detected within 24 hours of the onset of symptoms. The changes are specific enough in most cases to allow osteomyelitis to be differentiated from clinically similar conditions.

Ultrasound can also indicate the need for surgery. Only five of the 12 sites showing a periosteal sandwich required surgery, and no pus was found under the periosteum in any of them. Where the periosteum has been lifted off the bone by as much as $2 \mathrm{~mm}$ it is probable that pus is present. In 18 such cases we found subperiosteal pus in 16 and granulation tissue in the other two.

We found periosteal changes in all our cases of osteomyelitis, except those involving the iliac bone, but it was often necessary to search the suspected site for some time to find these changes. The initial involvement of the periosteum is not circumferential, and occurs only on one side of the bone. Ultrasound examination is therefore not complete until the whole circumference has been examined. This often requires turning the child during the investigation. The site of 'point tenderness' often corresponded to the site of periosteal elevation, but not always.

The place of surgery in the treatment of acute osteomyelitis is still controversial, but even those surgeons who favour conservative management agree that pus should be drained as early as possible (Harris 1960; Blockey and Watson 1970; Ek 1971; Blockey and McAllister 1972; Dich et al 1975; O'Brien et al 1982; Cole et al 1982; Nade 1983; LaMont et al 1987). It may be difficult to detect pus by clinical examination and although aspiration may reveal an abscess, a negative result can be due to wrong placement of the needle (Blockey and Watson 1970). Ultrasound is a nontraumatic examination, and many of the children actually enjoyed it. It is possible to scan the entire bone, and diagnostic aspiration is not needed. The finding of a periosteal sandwich with little or no elevation does not rule out the eventual need for surgery, but it does justify a trial of conservative management.

Ultrasound has proved to be an extremely useful diagnostic tool, which can distinguish between early cases which justify a trial of conservative management, and more advanced cases which require immediate surgical drainage.

No benefits in any form have been received or will be received from a commercial party related directly or indirectly to the subject of this article.

\section{REFERENCES}

Abiri MM, Kirpekar M, Ablow RC. Osteomyelitis : detection with US Radiology 1989; 172:509-11.

Blockey NJ, McAllister TA. Antibiotics in acute osteomyelitis in children. J Bone Joint Surg [Br] 1972; 54-B:299-309.

Blockey NJ, Watson JT. Acute osteomyelitis in children. J Bone Joint Surg [ Br] 1970; 52-B:77-87.

Capitanio MA, Kirkpatrick JA. Early roentgen observations in acute osteomyelitis. Am J Roentgenol 1970; 108:488-96.

Cole WG, Dalziel RE, Leitl S. Treatment of acute osteomyelitis in childhood. J Bone Joint Surg [ Br] 1982; 64-B :218-23.

Dich VQ, Nelson JD, Haltalin KC. Osteomyelitis in infants and children: a review of 163 cases. Am J Dis Child 1975; 129:1273-8.

Ek J. Acute hematogenous osteomyelitis in infancy and childhood. Clin Pediatr 1971; 10:377-9.

Fleisher GR, Paradise JE, Plotkin SA, Borden S. Falsely normal radionuclide scans for osteomyelitis. Am J Dis Child 1980; 134 : 499-502.

Gold R. Diagnosis of osteomyelitis. Pediatr Rev 1991 ; 12:292-7.

Harris NH. Some problems in the diagnosis and therapy of acute osteomyelitis. J Bone Joint Surg [Br] 1960; 42-B :535-41.

Howard CB, Einhorn MS. Ultrasound in the detection of subperiosteal abscess. J Bone Joint Surg [Br] 1991 ; 73-B:175-6.

LaMont RL, Anderson PA, Dajani AS, Thirumoorthi MC. Acute hematogenous osteomyelitis in children. J Pediatr Orthop 1987; 7:579-83.

Nade S. Acute haematogenous osteomyelitis in infancy and childhood. J Bone Joint Surg [Br] 1983; 65-B:109-19.

O'Brien T, McManus F, MacAuley PH, Ennis JT. Acute haematogenous osteomyelitis. J Bone Joint Surg [Br] 1982; 64-B:450-3.

Scoles PV, Hilty MD, Sfakianakis GN. Bone scan patterns in acute osteomyelitis. Clin Orthop 1980; 153:210-7.

Scott RJ, Christofersen MR, Robertson WW, et al. Acute osteomyelitis in children: a review of 116 cases. J Pediatr Orthop 1990; 10 : 649-52.

Sullivan DC, Rosenfield NS, Ogden J, Gottschalk A. Problems in the scintigraphic detection of osteomyelitis in children. Radiology $1980 ; 135: 731-6$

Waldvogel FA, Vasey H. 'Osteomyelitis': the past decade. $N$ Engl J Med $1980 ; 303: 360-70$. 